\title{
Campylorhamphus procurvoides successor (Aves: Dendrocolaptidae) is a junior synonym of Campylorhamphus trochilirostris notabilis
}

\author{
Carlos Eduardo Portes $^{1} \&$ Alexandre Aleixo ${ }^{2}$
}

\begin{abstract}
1 Programa de Pós-Graduação em Zoologia, Universidade Federal do Pará, Museu Paraense Emilio Goeldi. Caixa Postal 399, 66040-170 Belém, Pará, Brasil. E-mail: dudaportes@yahoo.com.br

2 Coordenação de Zoologia, Museu Paraense Emilio Goeldi. Caixa Postal 399, 66040-170 Belém, Pará, Brasil.

E-mail: aleixo@museu-goeldi.br
\end{abstract}

\begin{abstract}
The taxonomy of the genus Campylorhamphus Bertoni, 1901 is still uncertain, with many inconsistent evolutionary patterns implied by current taxonomy. A re-analysis of the type-series of Campylorhamphus procurvoides successor Todd, 1948 revealed that the holotype is indistinguishable from Campylorhamphus trochilirostris notabilis Zimmer, 1934, while the paratypes belonged either to the latter taxon or to a second already named taxon (Campylorhamphus trochilirostris snethlageae Zimmer, 1934), and a third and yet undescribed taxon allied to Campylorhamphus procurvoides. Here, we present statistical analyses of morphological data supporting the synonymization of $C$. $p$. successor into $C$. $t$. notabilis, the name with priority. Our findings resolve the long-standing controversy related to the distribution of Campylorhamphus procurvoides populations in the várzea habitats of the lower Amazon River.
\end{abstract}

KEY WORDS. Distribution; habitat selection; synonymization; terra-firme forest; taxonomy; várzea forest.

The biological polytypic species Campylorhamphus procurvoides (Lafresnaye, 1850) is endemic to the Amazon basin, where it occurs throughout the region (Zimmer 1934, Peters 1951, Ridgely \& Tudor 1994). The last taxonomic revision available for C. procurvoides dates back to the 1930's, when ZimMER (1934) described two new subspecies (C. procurvoides probatus Zimmer, 1934 and C. procurvoides sanus Zimmer, 1934), and established the current interspecific limits between the polytypic $C$. procurvoides and its closely allied species $C$. trochilirostris (Lichtenstein, 1820). Subsequently, the only taxon associated with the polytypic C. procurvoides was $C$. procurvoides successor Todd, 1948 (TodD 1948).

Recently, MARANTz et al. (2003) pointed out some inconsistencies in the known distribution of C. p. successor, which, as currently defined, includes two completely disjunct populations: one distributed throughout western Amazonia in the Brazilian states of Acre and Amazonas, and a second one apparently restricted to the Óbidos area in the lower Amazon River, state of Pará. The occurrence of C. p. successor in Óbidos is based on a series of Campylorhamphus Bertoni, 1901 specimens collected in 1922 during the Samuel M. Klages expedition on river islands in the vicinity of Óbidos; later on, those specimens were used in the description of C. p. successor and incorporated into its type series (ToDD 1948).

According to Marantz et al. (2003), the fact that some paratypes of C. p. successor came from an "island near Óbidos", in the lower Amazon River (TodD 1948), implies either one of the following inconsistent scenarios: 1 ) that $C$. procurvoides (known to be associated exclusively with upland terra-firme forest) is also found in floodplain várzea forest (the main vegetation type associated with the islands), a notion not supported by field work carried out by several authors along the banks and islands of the lower Amazon valley, where only $C$. trochilirostris snethlageae Zimmer, 1934 has been recorded (Snethlage 1913, Marantz et al. 2003, Cohn-Haft et al. 2007); or 2) since nominate $C$. $p$. procurvoides has also been collected at Óbidos (but not on the islands), the latter taxon and C. p. successor would be are sympatric in this particular region, a situation not found elsewhere throughout the distribution of the species, where the different taxa replace each other parapatricaly (ZimMer 1934, Marantz et al. 2003).

Here, we evaluate those aforementioned inconsistencies and re-analyze the type series of $C$. $p$. successor based on morphometric and plumage characters in the context of a broader study on the systematics of the polytypic C. procurvoides.

\section{MATERIAL AND METHODS}

We measured morphometric and plumage characters of 397 study skins of all described taxa of Campylorhamphus deposited in the following museums: American Museum of Natural History, New York, USA (AMNH), Carnegie Museum of Natural History, Pittsburgh, USA (CM), Colección Ornitológica Phelps, Caracas, Venezuela (COP), Field Museum of Natural History, Chicago, USA (FMNH), Museum of Natural Science, Louisiana State University, Baton Rouge, USA (LSUMZ), Museu de Zoologia da Universidade de São Paulo, São Paulo, Brazil 
(MZUSP), Museum of Comparative Zoology, Cambridge, USA (MCZ), Museu Paraense Emílio Goeldi, Belém, Brazil (MPEG), Naturhistoriska Riksmuseet, Stockholm, Sweden (NR), Museum für Naturkunde, Berlin, Germany (ZMB), and Naturhistorisches Museum, Vienna, Austria (NHMW).

After the analysis of such a large series of specimens, it became evident mainly due to discrete plumage characters, that the re-analysis of $C$. p. successor type series justified the inclusion of only the remaining taxa in the same polytypic species (multostriatus, probatus, procurvoides, and sanus) in addition to those of $C$. trochilirostris occurring in the Amazon basin (devius, napensis, notabilis, and snethlageae), also the only representative taxa of the genus Campylorhamphus in the region. Therefore, 200 study skins from 121 localities belonging to those taxa were analyzed (including all holotypes), among them 180 specimens of $C$. procurvoides from 104 localities and 20 specimens of C. trochilirostris from 11 localities (Appendix).

Our analyses were based on 18 morphometric as well as continuous and discrete plumage characters. Continuous characters were measured with a Mitutoyo ${ }^{\circledR}$ digital caliper to the nearest $0.01 \mathrm{~mm}$ or counted. The following morphometric characters were measured: 1 ) wing length - flattened (hereafter abbreviated $\mathrm{W}$ ); 2) tail length - from the insertion of the rectrices into the pygostyle to their outermost tip (T); 3) tarsometatarsus length - from the tibia - tarsometatarsus articulation to the base of the hallux (TM); 4) culmen - from the anterior edge of nares to the tip of the bill (C); 5) bill height taken along the nares (BH), and 6) bill width - taken along the nares (BW). Plumage analyzes were based on the following continuous and discrete characters: 1 ) number of feather stripes (spots) within a $0.7 \mathrm{~cm}^{2}$ square placed at the center of the breast (PS); 2) number of spots within a $0.7 \mathrm{~cm}^{2}$ square placed at the top of the head (HS); 3) number of spots within a $0.7 \mathrm{~cm}^{2}$ square placed at the center of the back (BS); 4) head color; 5) intensity of the black edge of pectoral, head, and dorsal spots (BES); 6) shape of pectoral, head, and dorsal spots (SS); 7) average length of pectoral spots (LPS), which was obtained from measurements of five different randomly chosen feathers in the body part of interest, the same applying to the characters as follows: 8) average width of pectoral spots (WPS); 9) average length of back spots (LBS); 10) average width of back spots (WBS); 11) average length of head spots (LHS), and 12) average width of head spots (LHS). General color designations for describing the plumage of the specimens analyzed followed SMiTHE (1975).

All measured characters were tested for normality with Kolmogorov-Smirnov tests with samples separated by taxon and sex. Sexual dimorphism was evaluated for each character separately with two-sample T-tests. One-way ANOVA and a Multivariate Discriminate Function Analysis (DFA) were used to test for significant differences in all continuous characters measured among the different taxa analyzed. All tests were performed with the SYSTAT version 10.2 software at the $95 \%$ confidence level.

\section{RESULTS}

\section{Sexual dimorphism}

Komogorov-Smirnov tests indicated that all measured characters had a normal distribution, therefore allowing the use of parametric tests. Two-sample T-tests for all characters showed significant sexual dimorphism in all taxa, mainly in wing length (multostriatus, napensis, probatus, procurvoides, snethlageae e successor), but also tail length (multostriatus, probatus e procurvoides), bill width (probatus e sanus), and average width of pectoral spots (sanus e napensis). No sexual dimorphism was observed in any of the evaluated discrete plumage characters. Since sexual dimorphism in continuous characters did not occur for the same characters across all taxa, all remaining statistical analyzes presented below included only male specimens $(n=119)$, as they were better represented in the sampling than females $(n=68)$.

\section{Type series of Campylorhamphus procurvoides successor}

Tond (1948) included 19 specimens in the type series of $C$. p. successor, examined directly by us at the CM. Morphological analyzes of 15 of those specimens (four additional paratypes were exchanged with different museums not visited by us) showed that paratypes CM 86702, CM 87386, CM 87857, CM 91898, and CM 96192 (hereafter called group 1 paratypes) differed in many characters from the holotype (CM 923171) and remaining paratypes (CM 84313, CM 84324, CM 84671, CM 84672, CM 93425, CM 93648, CM 93992, CM 99030, and CM 99363; hereafter called group 2 paratypes). Those differences pertained mostly to discrete plumage characters, which consistently approached group 1 paratypes to taxa of $C$. procurvoides distributed north of the Amazon River (C. p. procurvoides and C. p. sanus).

The main discrete plumage characters making the diagnosis between group 1 paratypes and the holotype and group 2 paratypes are as follows: 1) breast with a predominant dark brownish olive color (color 129 in SMITHE 1975), whereas in the holotype and group 2 paratypes the breast is predominantly grayish brown (color 121 - Vandyke Brown - in SMITHE 1975); 2) pectoral stripes of group 1 paratypes have a distinct sagitate shape, with an arrow-shaped tip, whereas the holotype and group 2 paratypes have larger spots with overall cylindrical shapes and not so thinned tips; and 3) the pectoral spots of the holotype and group 2 paratypes have a more conspicuous black edge than those found among specimens of group 1 paratypes.

A two-sample T-test comparing averages obtained for all characters with continuous variation (except plumage character ND, absent in a few individuals) between males of group 1 paratypes ( $n=5)$ and the holotype (also a male) and males of group 2 paratypes $(n=7)$ indicated significant differences in the following characters: 1$)$ bill length $(t=-2.463$, d.f. $=10$, $\mathrm{p}=0.044) ; 2$ ) bill width ( $\mathrm{t}=-2.242$, d.f. $=9, \mathrm{p}=0.047)$, and 3 ) number of spots within a $0.7 \mathrm{~cm}^{2}$ area at the top of the head $(\mathrm{t}=2.674$, d.f. $=10, \mathrm{p}=0.020)$. 
The holotype and group 2 paratypes do not approach any of the taxa grouped under C. procurvoides, but instead two other taxa grouped under a different polytypic species: $C$. trochilirostris notabilis and C. trochilirostris snethlageae. In fact, the holotype and specimens of group 2 paratypes distributed west of the Madeira River in western Amazonia (CM 93425, 93648, 93992, 99030, and 99363) are indistinguishable from specimens of the type series of $C$. trochilirostris notabilis obtained along the Madeira River (AMNH 282318, 282311, and 525235), as shown by the cylindrical and wider shape of their pectoral, dorsal, and head spots, in addition to the contrasting black edge of their pectoral feather stripes. On the other hand, group 2 paratype specimens from Óbidos in the lower Amazon (CM 84313, 84324, 84671, and 84672) are indistinguishable from those of C. t. snethlageae, as indicated by the conspicuous reddish tinge (color 136 - Raw Sienna - in SMithe 1975) of their underparts, a character which consistently makes the diagnosis of the latter taxon (Zimmer 1934).

Therefore, the type series of C. p. successor consists of a mixture of specimens belonging to three different taxa, two of them described earlier than successor itself: C. $t$. notabilis (including the C. p. successor holotype - CM 923171 - and group 2 paratypes CM 93425, 93648, 93992, 99030, and 99363), C. t. snethlageae (including group 2 paratypes CM 84313, 84324, 84671, and 84672), in addition to a third and yet undescribed taxon belonging to the $C$. procurvoides group (including all group 1 paratype specimens CM 86702, 87386, 87857, 91898, and 96192; Fig. 1).

To further corroborate the hypothesis that C. p. successor type series is a composite of three different taxa belonging to two different species (C. procurvoides and C. trochilirostris), we carried out a Discriminate Function Analysis (DFA) based on

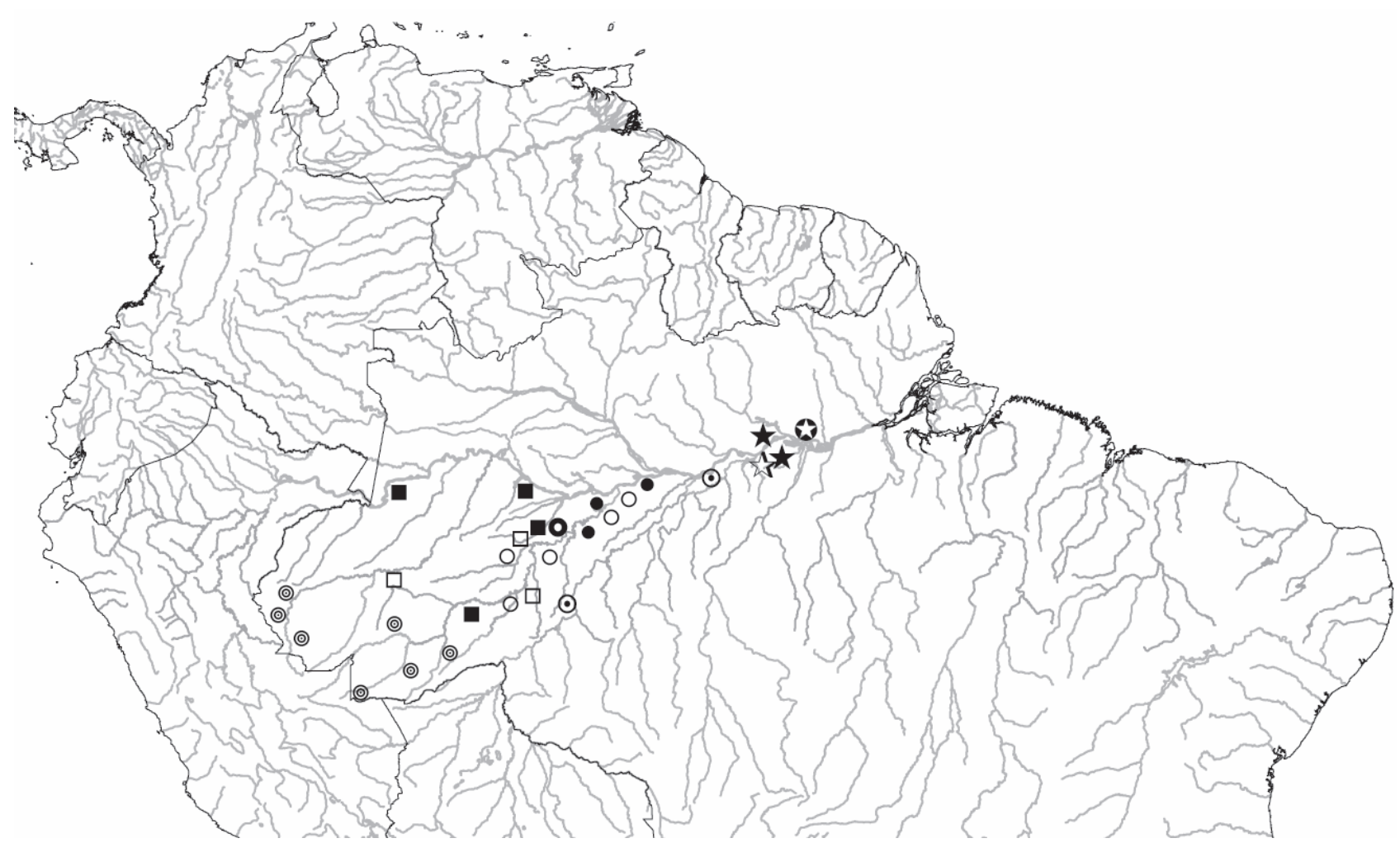

Figure 1. Distribution of relevant specimens for the synonymization of C. procurvoides successor into C. trochilirostris notabilis. (Stars) Localities of specimens classified as C. trochilirostris snethlageae in the present study (dark stars), including the holotype (white star), and paratypes of C. p. successor collected in the Óbidos area, state of Pará (white star inserted in a black circle). (Circles) Localities of specimens classified as C. trochilirostris notabilis in the present study, including its holotype and paratypes (white circles with a small dot in the center), the holotype of C. $p$. successor (dark circle with a white dot in the center), some paratypes of C. $p$. successor (dark solid circles), and recently collected specimens from the state of Acre deposited at MPEG (concentric hollow circles). (Squares) Localities of C. $p$. successor group 1 paratypes belonging in fact to an undescribed taxon related to C. procurvoides (solid dark squares), and localities mentioned by GyLdenstolpe (1951) for C. p. successor, but which refer in fact to the undescribed C. procurvoides taxon (white squares). Localities denoted by solid white circles are those reported by GYLDENSTOLPE (1951) for 13 C. t. notabilis specimens collected along the Purus River which have not been directly examined, but whose identification is consistent with the results obtained in this study. 
all 15 morphometric and continuous plumage characters measured and a larger series of specimens, which included modern specimens in addition to those of successor type series. This analysis tested the diagnosis in the multivariate space of a group of specimens from western Amazonia belonging to the undescribed taxon allied to C. procurvoides, thus with the same characteristics as group 1 paratypes $(\mathrm{n}=10$; CM 86702, CM 87386, CM 87857, CM 91898, CM 96192, MPEG 60081, MPEG 62267, MZUSP 76641, NR 569481, NR 569482), against a second group with males of two C. trochilirostris taxa (C. t. notabilis and C. t. snethlageae), in addition to the holotype and group 2 paratypes of C. p. successor $(\mathrm{n}=27$; $\mathrm{AMNH} 278076, \mathrm{AMNH}$ 278745, AMNH 282310, AMNH 284143, AMNH 525235, CM 84313, CM 84672, CM 923171, CM 93425, CM 93992, CM 99030, CM 99363, MPEG 43152 - 43153, MPEG 48154, MPEG 52090 - 52091, MPEG 52890, MPEG 56638, MPEG 59812 59813, MPEG 61273 - 61276, MPEG 61478). The DFA classified correctly all specimens in those two groups (Wilks' lambda $=0.1628 ; \mathrm{F}=7.3469$ d.f. $=14133 ; \mathrm{p}=0.001$ ), thus reinforcing the previous results and showing that the C. p. successor holotype is in fact a specimen of $C$. trochilirostris.

\section{DISCUSSION}

In the latest extensive taxonomic review of Campylorhamphus, ZIMMER (1934) discussed on a female (AMNH 309432) from Tefé, Amazonian Brazil, which posed a serious identification challenge: it could not be classified with certainty as either $C$. procurvoides or $C$. trochilirostris, even though the shape of its pectoral spots was similar to those of birds grouped under $C$. procurvoides by Zimmer himself; therefore, ZIMMER (1934) was unable to identify the Tefé specimen, particularly because he had just a single individual at hand.

Subsequently, the enigmatic Tefé Campylorhamphus was also mentioned by Gyldenstolpe (1945), who studied a female Campylorhamphus (NR 569483) obtained by the Olalla family at Igarapé Grande, upper Juruá River, near Eirunepé, state of Amazonas, Brazil, and sold to the NR in Stockholm, Sweden. Gyldenstolpe (1945) concluded that this particular specimen and two further males also housed at the NR and collected by the Olallas along the Purus River valley at Lábrea and Jaburú (respectively NR 569481 and 569482), also in the state of Amazonas, closely matched the characters shown by the Tefé specimen discussed by Zimmer (1934), and that as a whole, those specimens probably represented an yet undescribed taxon allied to C. procurvoides. Instead of describing the new taxon, Gyldenstolpe (1945) was cautious and decided not to name it until a larger series of specimens from the Juruá and Purus River basins became available (GyLdENSTOLPE 1945).

Three years later, TodD (1948) studied a series of 19 Campylorhamphus obtained by the collector Samuel M. Klages at six different localities along the Purus, Solimões, and lower Amazon rivers between 1921 and 1924, and sold to the CM in Pittsburgh. Todd (1948) also examined the Tefé specimen dis- cussed by Zimmer (1934), and concluded that they all belonged, along with the male from the upper Juruá housed at the NR, to the new taxon recognized but not named by GYLDENSTOLPE (1945); he then provided a brief description of the new taxon, which was named Campylorhamphus procurvoides successor Todd 1948 (type locality Nova Olinda, on the left bank of the middle Purus River, state of Amazonas, Brazil; Fig. 1). Subsequently, on his detailed study on the ornithology of the Purus River region in Brazil, Gyldenstolpe (1951) also assigned his Lábrea and Jaburú specimens mentioned above to C. p. successor, even without having examined the type series at the CM. He probably based his decision on the following facts: 1) the NR Purus specimens were collected near the C. p. successor's type locality; and 2) they fit well the description of the Tefé specimen discussed by ZIMMER (1934), which was also included by TodD (1948) in C. p. successor type series. Nevertheless, GyLdENSTOLPE (1951: 153) expressed some doubt as to the actual distribution of C. p. successor as defined in Todd's original description: "Todd also refers examples from São Paulo de Olivença and Caviana (opposite Manacapurú) on the Rio Solimões to his C. p. successor, a form which - if Todd is correct in his identification - reappears on the island near Óbidos, Lower Amazonia". Gyldenstolpe (1951) was already pointing to the ecological and biogeographical inconsistencies surrounding the taxon successor mentioned earlier.

Morphometric and plumage analyzes reported herein showed that Todd (1948) mixed in the type series of C. p. successor specimens of an yet undescribed taxon allied to the procurvoides group already discussed by ZIMMER (1934) and Gyldenstolpe (1945), with specimens of two taxa allied to the trochilirostris group which had already been described by ZIMMER (1934) in the Brazilian Amazon (C. t. notabilis and C. $t$. snethlageae); this mistake was worsened by his choice as the holotype of a specimen indistinguishable from those making up the type series C. t. notabilis. Therefore, we propose here the synonimization of C. p. successor and C. t. notabilis, which stresses the need of a valid description for the new taxon allied to the procurvoides group. This description, along with a multicharacter taxomomic review of the polytypic C. procurvoides, is currently under way and is being conducted by the authors of this contribution and other co-authors.

In addition to the fact that the holotypes of C. t. notabilis and C. p. successor are not mutually diagnosed, they also differ consistently in some characters from their respective type series, underscoring the high degree of plumage variation found in Amazonian populations of $C$. trochilirostris. The following findings reinforce the impossibility of a consistent diagnosis between notabilis e successor: 1) the pectoral spots of the notabilis holotype have no black edges, while those of the paratypes (AMNH 525235,282310 e 282311) do, inasmuch as those of the holotype and group 2 paratypes of successor; 2 ) the head stripes of the notabilis holotype are bigger and wider, differing markedly from those of the paratypes, which are more similar in size to those of the successor holotype; and 3) the holotype of notabilis 
possesses whitish to yellowish pectoral spots, while those of the paratypes and the successor holotype are cinnamon white.

Thus, with the synonymization of $C$. p. successor into $C$. t. notabilis it is finally possible to solve the apparent biogeographic and ecological contradiction involving the presence of a taxon of the polytypic C. procurvoides in floodplain várzea forests on islands of the lower Amazon (Gyldenstolpe 1951, Marantz et al. 2003). As the analyzes presented here showed, all Óbidos specimens of successor, key for solving the controversy, belong in fact to the previously described várzea specialist C. t. snethlageae, a notion also supported by recent field work and specimen collection by several authors in the lower Amazon area (Marantz et al. 2003, Cohn-Haft et al. 2007).

\section{ACKNOWLEDGMENTS}

We thank Fátima Lima (MPEG) for her support during data collection and J.M. Bates and J.D. Weckstein (FMNH) for their invaluable financial and logistical support. J.L. Cracraft and P.R. Sweet (AMNH), B.C. Livezey and S.P. Rogers (CM), M. Lentino (COP), J.V. Remsen Jr and S.W. Cardiff (LSUMZ), E. Bauerfeind (NHMW), G. Frisk (NR), L.F. Silveira (MZUSP), and S. Frahnert (ZMB) allowed access and provided loans of specimens under their care. M.A. Raposo kindly allowed the consultation of a high fidelity digital picture of the holotype of $C$. procurvoides procurvoides, made possible by the project "Catálogo de tipos das espécies de aves brasileiras e repatriação de dados dos espécimes tipo depositados em coleções estrangeiras", supported by CNPq (479049/2006-8). During this study CEP held a Master's fellowship granted by CNPq.

\section{LITERATURE CITED}

Cohn-Haft, M.; L.N. Naka \& A.M. Fernandes. 2007. Padrões de distribuição da avifauna da várzea dos rios Solimões e Amazonas, p. 287-323. In: A.L. Albernaz (Ed.) Conservação da várzea: identificação e caracterização de regiões biogeográficas. Manaus, Ibama, ProVárzea, 356p.

Gyldenstolpe, N. 1945. The bird fauna of rio Juruá in western Brazil. Kungliga Svenska Vetenskapsakademien Akademiens Handlingar 22 (3): 1-337.

Gyldenstolpe, N. 1951. The ornithology of the Rio Purús region in western Brazil. Arkiv för Zoologi 2 (1): 1-230.

Marantz, C.; A. Aleixo; L.R. Bevier \& M.A. Patten. 2003. Family Dendrocolaptidae (Woodcreepers), p. 358-447. In: J. DEL Hoyo; A. Elliott \& D. Christie (Eds). Handbook of the birds of the world. Barcelona, Lynx Edicions, vol. 8, 845p.

Peters, J.L. 1951. Check-list of birds of the world. Cambridge, Harvard University Press, vol. 7, 315p.

Ridgely, R.S. \& G. Tudor. 1994. The birds of South America: the oscines passerines. Austin, University Texas Press, 516p.

Smithe, F.B. 1975. Naturalist's color guide. New York, America Museum Natural History, 22p.

Snethlage, E. 1913. Über die Verbreitung der Vogelarten in Unteramazonien. Journal für Ornithologie 61: 469539.

ToDD, W.E.C. 1948. Critical Remarks on the wood-hewers. Annals of the Carnegie Museum 31: 73: 5-18.

Zimmer, J.T. 1934. Studies on Peruvian Birds XIII. The genera Dendrexetastes, Campylorhamphus, and Dendrocincla. American Museum Novitates 728: 1-15.

Appendix. Specimens examined in this study; those followed by an asterisk are holotypes.

\section{Campylorhamphus procurvoides procurvoides (Lafresnaye, 1850)}

BraZIL, Amazonas: Faro (AMNH 284142 female, 284144 male, 284145 male, and 284146 female). Amapá: Município de Mazagão, Igarapé Novo (MPEG 16510 male, 29507 male, 29508 female, and 29510 female), Macapá (MPEG 20486 male), Rio Araguari (MPEG 21043 male). Pará: Óbidos (CM 83573 male), Faro (MPEG 64656 male and 64657 male). GuYANA, Bart. District (AMNH 805823 male). Mines District (AMNH 525232 female and 525233 unsexed), Carimang River (AMNH 525231 female), Katarbo (AMNH 805821 male, 805820 male and 805822 male), Tumatumari, Tataro River (AMNH 125799 female). SurINAM, Nickerie: West River, Wilhelmina Mts (FMNH 260353 male), Negerkreek (AMNH 461481 male). French GuYANa: Ipousin (AMNH 525230 female), Germanaco, Mana River (AMNH 233882 male), Saut Tamanoir (CM 61239 male, 61603 female, 62347 male, 62392 female, and 62461 male). Venezuela, Bolívar: Río Ridairo, near the border with Guyana (COP 4258 female), Altiplanice de Muria, Sierra de Imataca (COP 16949 male and 16950 female), Camborere, Cano El Buey, tributary of río Cuyuni (COP 46105 male) and El Venamo (COP 67923 female and 67924 male). Specimens examined only through pictures: BrazIL, Pará: Faro, Rio Jacundá (ZMB 31831female) and Óbidos, Colônia de Veado (ZMB 31832 female).

Specimens examined only through pictures: FrenCH GuYANA: Cayenne (MCZ 77120*, unsexed).

\section{Campylorhamphus procurvoides sanus Zimmer, 1934}

Brazil, Amazonas: Povoado de Santa Cruz, Rio Negro (MPEG 31684 male), Tatu, Rio Negro (AMNH 271133 unsexed, 434735 male, and 434736 male). Colombia, Putumayo: Santo Antonio Guamez (AMNH 286993 male and 293224 male). Caquetá: Río Bodoqueira (AMNH 116480 female). Meta: Villavicencio (AMNH 122111 female). VenezuelA, Amazonas: Cerro de la Neblina (FMNH 319013 male), Mt. Duida, Campamento del Medio (AMNH 274270* male), Solano (AMNH 433077 male), Rio Negro, Curycuryai, Píe del Cerro (AMNH 310843 male and 310844 male), Monte Duida, Píe del Cerro (AMNH 274269 male), Monte Duida, Carrão Seco 
(AMNH 271131 male), Opposite of el Merey, Tahuapunto (AMNH 433078 female), Monte Duida, Esmeralda (AMNH 274272 female), Monte Duida, Playa del Río Base (AMNH 274268 male), Río Orinoco, Boca do Río Oçamã (AMNH 432076 female), Tahuapunto, Río Uaupes (AMNH 434734 male), Camp. La Cruz, Yarrita-Pumichin, Amazonas (COP 34384 female). Peru, Loreto: Quebrada Orán, ca. 5 Km N Río Amazonas, 85 Km NE of Iquitos (LSUMZ 119612 male, 119613 male, and 119614 male).

\section{Campylorhamphus procurvoides multostriatus (Snethlage, 1907)}

BraziL, Pará: Serra dos Carajás (MPEG 35289 female, 36737 male, and 38290 male), Jacundá (MPEG 36086 female), Aveiro (MZUSP 14654 male and 14655 female), Fazenda do Rio Curuá (MZUSP 2337 male), Urucurituba (MZUSP 40672 female), Fordlândia (MZUSP 58540 male), Altamira (MEPG 30164 unsexed and 55385 female), Rodovia Santarém-Cuiabá (Km 84) (MPEG 36490 male, 36491 female, 40591 male, and 47710 male), Santarém (CM 71504 male, 73210 male, 73459 male, and 78142 female; FMNH 254755 male), Colônia de Mojuy (CM 74484 male, 74750, male, 74971 female, and 75067 male), Miritituba (CM 76698 female and 286954 female), Aranamay, Rio Tapajós (AMNH 286955 female), Caxiricatuba, Rio Tapajós (AMNH 286956 male, 286957 male, and 286959 unsexed), Victoria, Rio Xingu (AMNH 128595 male). Mato Grosso: Alta Floresta (MPEG 51427 male and 51428 female), Fazenda São José, Rio Peixoto de Azevedo (MEPG 33625 female).

Specimens examined only through pictures: BrazlL: Pará: Arumateua, Rio Tocantins (ZMB 31828* male).

\section{Campylorhamphus procurvoides probatus Zimmer, 1934}

BrazIL, Pará: Juruti, Acampamento Barroso (MPEG 60954, unsexed), Igarapé Amazônia, Rio Tapajós (AMNH 288694 female), Igarapé Barato, Rio Tapajós (AMNH 286952 male), Sinval, Rio Tapajós (AMNH 288695 male and 288696 male), Boim (AMNH 128596 female), Itaituba (CM 77107 female), Vila Braga (CM 75291 male, 75726 female, 76065 male, 76145 male, and 76584 female). Amazonas: Igarapé Aurá, Rio Madeira (279769 male, 279770 male, and AMNH 279773* female), Igarapé Aiubá, Rio Madeira (AMNH 279771 female and 279772 female), Vila Bela Imperatriz (AMNH 278074 male, 278075 male, 278077 female, 278078 female, and 278744 male), Rosarinho (AMNH 282309 male), Manicoré (MPEG 57584 female). Rondônia: Ouro Preto do Oeste (MPEG 37033 female and 37034 male), Pedra Branca (FMNH 343880 male), Cachoeira Nazaré (MPEG 39676 male and MPEG 39676 male), Alvorada do Oeste (MPEG 38737 male). Mato Grosso: Cachoeira Dardanelos (MPEG 31049 male).

\section{Campylorhamphus procurvoides ssp.}

BrAZIL, Amazonas: Careiro, BR-319 km 158, Tupana Lodge (MPEG 62267 male), RDS Cujubim, Jutaí (MPEG 60081 male), São Paulo de Olivença (CM 96192 male), Hyutanaãn (CM 86702 male, 87386 male, and 87857 male), Tefé (AMNH 309342 female), Nova Olinda (CM 91898 male), Purus, Salobra (NR 569481 male), Purus, Jaburu (NR 569482 male), rio Juruá, Igarapé Grande (NR 569483 female). Rondônia: Estação Ecológica Mujica Nava (MZUSP 76641 male).

\section{Campylorhamphus trochilirostris notabilis Zimmer, 1934}

BrAZIL, Amazonas: Humaitá (AMNH 525235 male), Rosarinho (AMNH 282310 male, 282311 unsexed, and 282312* female), Arimã (CM 93425 male, 93648 female, and 93992 male), Caviana (CM 99030 male and 99363 male), Nova Olinda (CM 923171 male). Acre: Porto Walter (MPEG 52890 male), Cruzeiro do Sul, Sobral (MPEG 48154 male), Marechal Taumaturgo (MPEG 52090 male, 52091 male, and 52092 female), Porto Acre (MPEG 59949 female), Estação Ecológica do Rio Acre (MPEG 59811 female, 59812 male, 59813 male, 59814 female, and 59815 female), Tarauacá, Floresta Estadual do Mogno, BR 364 (Km 6) (MPEG 60597 female), Manoel Urbano, BR 364 (MPEG 61478 male), Transacreana Km 70, ramal Jarinal (MPEG 61273 male, 61274 male, 61275 male, and 61276 male).

\section{Campylorhamphus trochilirostris snethlageae Zimmer, 1934}

BrazIL, Pará: Faro (AMNH 284143 male), Óbidos (CM 84313 male, 84324 female, 84671 female, and 84672 male), Juruti, Fazenda São Joaquim (MPEG 56638 male). Amazonas: Maraã (MPEG 43152 male, 43153 male, and 43154 female), Vila Bela Imperatriz (AMNH 278746 female, 278076 male, 278079 female, and $278745^{*}$ male).

Submitted: 21.VIII.2008; Accepted: 09.IX.2009.

Editorial responsibility: Ana Lúcia da Costa Prudente 